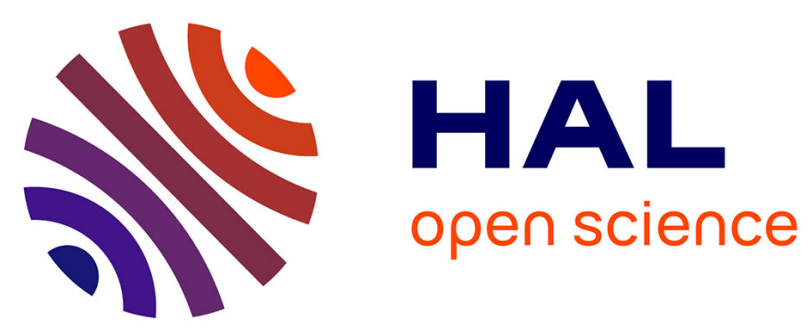

\title{
Interspecific and geographical variations of trace metal concentrations in cephalopods from Tunisian waters
}

\author{
Moncef Rjeibi, Marc Metian, Tarek Hajji, Thierry Guyot, Rafika Ben
}

Chaouacha-Chekir, Paco Bustamante

\section{- To cite this version:}

Moncef Rjeibi, Marc Metian, Tarek Hajji, Thierry Guyot, Rafika Ben Chaouacha-Chekir, et al.. Interspecific and geographical variations of trace metal concentrations in cephalopods from Tunisian waters. Environmental Monitoring and Assessment, 2014, 186 (6), pp.3767-3783. 10.1007/s10661014-3656-2 . hal-00984028

\section{HAL Id: hal-00984028 \\ https://hal.science/hal-00984028}

Submitted on 26 Apr 2014

HAL is a multi-disciplinary open access archive for the deposit and dissemination of scientific research documents, whether they are published or not. The documents may come from teaching and research institutions in France or abroad, or from public or private research centers.
L'archive ouverte pluridisciplinaire HAL, est destinée au dépôt et à la diffusion de documents scientifiques de niveau recherche, publiés ou non, émanant des établissements d'enseignement et de recherche français ou étrangers, des laboratoires publics ou privés. 


\section{INTERSPECIFIC AND GEOGRAPHICAL VARIATIONS OF TRACE METAL CONCENTRATIONS IN CEPHALOPODS FROM TUNISIAN WATERS}

Moncef Rjeibi ${ }^{\mathrm{a}, \mathrm{b}}$, Marc Metian ${ }^{\mathrm{b}}$, Tarek Hajji ${ }^{\mathrm{a}}$, Thierry Guyot ${ }^{\mathrm{b}}$, Rafika Ben ChaouachaChekir $^{\mathrm{a}}$, Paco Bustamante ${ }^{\mathrm{b}}$

${ }^{a}$ Unité de recherche d'Ecophysiologie et de Procédés Agroalimentaires UR11-ES44, Institut Supérieur de Biotechnologie de Sidi Thabet (ISBST), Université La Manouba, BiotechPole Sidi Thabet, Sidi Thabet CP 2020, Tunisia

${ }^{\mathrm{b}}$ Littoral Environnement et Sociétés (LIENSs), UMR 7266 CNRS-Université La Rochelle, 2 rue Olympe de Gouges, 17000 La Rochelle, France

*Corresponding author: Prof. Paco Bustamante Littoral Environnement et Sociétés

UMR 7266

Université de La Rochelle

2, rue Olympe de Gouges

17000 La Rochelle (France)

Tel.: (+33) 546507625

Fax: (+33) 546456284

E-mail: pbustama@univ-lr.fr 
ABSTRACT: The concentrations of 6 metals ( $\mathrm{Ag}, \mathrm{Cd}, \mathrm{Cu}, \mathrm{Hg}, \mathrm{Pb}$, and $\mathrm{Zn}$ ) were investigated and compared in three tissues (arms, digestive gland and mantle) of three cephalopod species from the Tunisian waters: the common octopus (Octopus vulgaris), the common cuttlefish (Sepia officinalis) and the European squid (Loligo vulgaris). Whatever the species or the sites, the digestive gland displayed the highest concentrations of $\mathrm{Ag}, \mathrm{Cd}, \mathrm{Cu}, \mathrm{Pb}$ and $\mathrm{Zn}$ highlighting its major role in their bioaccumulation and detoxification. This is also true for $\mathrm{Hg}$ but only for the digestive gland of O.vulgaris. Muscle from the arms and the mantle contained thus relatively low trace metal concentrations except for $\mathrm{Hg}$ in L.vulgaris and S.officinalis. Geographic comparison of metal concentrations in Tunisian cephalopods from 3 locations indicates that higher concentrations of $\mathrm{Ag}, \mathrm{Pb}$ and $\mathrm{Hg}$ were observed in cephalopods from northern and eastern coasts, whereas the highest Cd levels was detected in the southeastern reflecting different conditions of exposure. Comparing the trace element concentrations between species, $\mathrm{Ag}, \mathrm{Cd}, \mathrm{Cu}, \mathrm{Hg}$ and $\mathrm{Zn}$ concentrations were the highest in the digestive gland of octopuses. This may be related to the differences in ecological features and swimming behaviour among different cephalopod species. Effects of length and sex on metal levels were also considered, indicating a limited influence of sex on metal concentration.

KEYWORDS: Octopus, Cuttlefish, Squid, Trace elements, Bioaccumulation, Mediterranean sea 


\section{INTRODUCTION}

Metals in cephalopods have received increasing attention in last decades as these molluscs play a major role both as predator and prey in marine ecosystems (Boyle and Rodhouse 2005). As cephalopods bioaccumulate large quantities of various metals, they represent an important source of contaminants for their predators (e.g. Bustamante et al., 1998a, Dorneles et al., 2007). Cephalopods also represent an increasing resource for humans (Piatkowski et al., 2001) and consequently cephalopod catches raised dramatically these last decades (Boyle and Rodhouse, 2005; FAO, 2007).

Cephalopods are generally short-lived species, most of them reproducing between 1 to 2 years old and then die. Because of their short-life span and their capacity to bioaccumulate very high metal concentrations in their tissues, cephalopods were proposed as reliable biomonitoring species to follow the variation of pollutants in the marine environment over time (Seixas et al. 2005; Bustamante et al. 2006; Miramand et al. 2006; Pierce et al. 2008; Kojadinovic et al. 2011).

In the Mediterranean Sea, trace metal concentrations have been reported in different cephalopod species (i.e., Sepia officinalis, Octopus vulgaris and Eledone cirrhosa) collected from the Northern and Northeastern region (Renzoni et al., 1973; Miramand and Guary, 1980; Ayas and Ozogul, 2011). On the contrary, there is still limited information available on cephalopods from African coasts of the Mediterranean Sea (Stoepler et al., 1979). To the best of our knowledge, no data on metal concentrations in cephalopod species from Tunisia have been reported while the fisheries of these molluscs have a very high economic importance in this country. 
In this context, this study was undertaken (a) to investigate the geographical variations of trace metals in the different tissues of the European squid Loligo vulgaris, the common octopus Octopus vulgaris and the common cuttlefish Sepia officinalis in three locations of the Tunisian coast and (b) to establish comparison between species in every sampling sites (c) to examine the influence of size and the sex on metal concentration in cephalopods. For this purpose, $\mathrm{Ag}, \mathrm{Cd}, \mathrm{Cu}, \mathrm{Hg}, \mathrm{Pb}$ and $\mathrm{Zn}$ were determined in the digestive gland and the muscles (both mantle and arms) of Loligo vulgaris, O. vulgaris and S. officinalis.

\section{MATERIALS AND METHODS}

\section{Biological material and sample preparation}

Seventy one individuals belonging to three cephalopod species, the european squid Loligo vulgaris $(\mathrm{n}=24)$, the common octopus Octopus vulgaris $(\mathrm{n}=20)$ and the common cuttlefish Sepia officinalis $(\mathrm{n}=27)$ (see Table 1 for details), were sampled in April 2010 in three locations, all situated in the authorized fishing area of the Tunisian coast (Fig. 1).

The first location, Bizerte, lies in the north of Tunisia and characterized with many industrial activities especially plastic and iron industries (El Ati-Hellal et al., 2005). The second site, Monastir, is located in the middle of east coast of Tunisia; the coastal area of this city can be characterized as unpolluted, given the non apparent sources of contamination (Hamza-Chaffai et al., 1997; Banni et al., 2007; Jebali et al., 2007). The last sampling site, Sfax, is located in the Gulf of Gabés (southeastern coast of Tunisia) and is considered as a major hub for Tunisian aquatic resources, contributing to approx. $65 \%$ of the national production (CGP, 1996). Important industrial activities, mainly crude phosphate treatments, chemical industries, tannery and plastic plants, are being developed along this region, possibly affecting the local marine ecosystems (Hamza-Chaffai et al., 1995); (Boujelben, 1998); (Banni et al., 2005). 
Cephalopods were collected by nets or trawling by professional fishermen. From the moment organisms were caught, they were placed on ice for the time they were brought to the laboratory and then rapidly frozen at $-25^{\circ} \mathrm{C}$ in individual plastic bags until dissections. Each individual was then defrosted, weighed (total body weight) and measured (dorsal mantle length -DML-). The determination of the sex and maturity stage were also realized. The maturity stage was evaluated by direct observation of the reproductive structures colors. The origin, number of individuals and biological details of individuals for each species of cephalopods are given in Table 1. Subsequently, samples of arm muscle, mantle muscle and digestive gland were removed for trace metal analysis.

\section{Metal analysis}

After dissection, tissue samples were frozen at $-20^{\circ} \mathrm{C}$, freeze-dried during 3 days and then finely ground in a porcelain mortar with a pestle. One aliquot of approximately $300 \mathrm{mg}$ of each homogenized dry sample was digested with $5 \mathrm{ml}$ of $65 \%$ ultrapure $\mathrm{HNO}_{3}$ (Merck $\left.®\right)$ at $80^{\circ} \mathrm{C}$ until the solution was clear. Then acid was evaporated and the residue was dissolved in $0.3 \mathrm{~N}$ ultrapure nitric acid. Concentrations of $\mathrm{Ag}, \mathrm{Cd}, \mathrm{Cu}, \mathrm{Pb}$ and $\mathrm{Zn}$ were determined by flame and graphite furnace atomic absorption spectrophotometry with a Hitachi Z5000 with Zeeman correction. The total $\mathrm{Hg}$ concentrations in the powder obtained from the tissues were determined by analyzing $\mathrm{Hg}$ directly with an Advanced Mercury Analyzer (ALTEC AMA 254) on aliquots ranging from approx. $10 \mathrm{mg}$ of dry sample weighed to the nearest $0.01 \mathrm{mg}$ (Bustamante et al. 2006a). Certified reference materials, Dogfish Liver DOLT-4 (NRCC), Lobster Hepatopancreas Tort-2 (NRCC) and Dogfish Muscle DORM-2 (NRCC), were treated and analysed in the same way as the samples. The results for standard reference materials were in good agreement with certified values with recoveries ranging from $91 \%$ for Ag to 
$98 \%$ for $\mathrm{Hg}$ (Table 2). The detection limits $\left(\mu \mathrm{g} \mathrm{g}^{-1} \mathrm{dw}\right.$ ) were 0.03 for $\mathrm{Ag}, 0.034$ for $\mathrm{Cd}, 0.5$ for $\mathrm{Cu}, 0.005$ for $\mathrm{Hg}, 3.2$ for $\mathrm{Pb}$ and 3 for $\mathrm{Zn}$.

\section{Statistical analysis}

All data were tested for normality by Shapiro-test and homogeneity of variances by Bartlett's test. Since data did not respect the former assumptions of parametric analysis, non-parametric tests were applied. Kruskal-Wallis test (K-W test) followed by a multiple comparison test with Holm adjustment method was performed to detect differences between geographical areas, and between tissues in species. The level of significance for statistical analyses was always set at $\alpha=0.05$.

Principal Component Analysis (PCA) was used to investigate the distribution of metal concentrations in the selected tissues within the species from the 3 locations (for details on PCA used, see Metian et al. (2013).

Generalized Additive Models (GAMs) were used to identify size-related, spatial and sex trends in explaining variability in metals concentrations (Zuur 2007). GAMs were fitted to average log-transformed on metal concentrations in digestive gland, arms, and mantle for each species and the dorsal mantle (DML) was considered as a continuous explanatory variable, while the sex and the location were treated as categorical explanatory variables in the model. The assumption of Gaussian error distributions was finally checked through the residuals of the model (homogeneity, normality, and no obvious pattern in residuals in general). All statistical analyses were performed using the free software R (R Development Core Team, 2010).

\section{RESULTS}

\section{Metal concentrations and tissue distribution}


$\mathrm{Ag}, \mathrm{Cd}, \mathrm{Cu}, \mathrm{Hg}, \mathrm{Pb}$ and $\mathrm{Zn}$ concentrations in the 3 selected tissues (digestive gland, arms, and mantle) of L. vulgaris, O. vulgaris, and S. officinalis are illustrated in Figure 2. Compared with the other tissues examined and regardless of the geographic location, the digestive gland contained the highest levels of $\mathrm{Ag}, \mathrm{Cd}, \mathrm{Cu}, \mathrm{Pb}$, and $\mathrm{Zn}(\mathrm{K}-\mathrm{W}$ test, $\mathrm{p}<0.001)$ in all species. Concentration of $\mathrm{Hg}$ was also significantly higher $(\mathrm{K}-\mathrm{W}, \mathrm{p}<0.001)$ in the digestive gland of O. vulgaris whereas its concentrations did not show significant differences among tissues of L. vulgaris and S. officinalis (K-W test, $\mathrm{p}>0.05)$. In all species and with the exception of $\mathrm{Hg}$, metal concentrations in the muscle were relatively low and were in the same range of concentration among the species.

\section{Geographical variation}

Metal concentrations in the tissues of cephalopods greatly differ both with species and sampling sites (Fig. 2). Hg concentrations were significantly higher $(\mathrm{K}-\mathrm{W}, \mathrm{p}<0.05)$ in $L$. vulgaris from Bizerte and Monastir compared to Sfax for all tissues. The same pattern was observed for $\mathrm{Cd}, \mathrm{Cu}$ and $\mathrm{Zn}$ concentrations with significantly higher $\mathrm{Cd}$ and $\mathrm{Zn}$ concentrations in the arms and in the digestive gland in squids from Monastir $(\mathrm{K}-\mathrm{W}, \mathrm{p}<0.05)$ and higher $\mathrm{Cu}$ concentrations in the mantle in squids from Bizerte $(\mathrm{K}-\mathrm{W}, \mathrm{p}<0.01)$ compared to those from Sfax.

In $O$. vulgaris, specimens from Monastir and Bizerte showed also significantly higher $\mathrm{Cu}$ and Hg concentrations $(\mathrm{K}-\mathrm{W}, \mathrm{p}<0.05)$ in the arms than those of Sfax. On the contrary, Cd concentrations in the digestive gland and the muscle tissues were higher $(\mathrm{K}-\mathrm{W}, \mathrm{p}<0.05)$ in Sfax than in the other sites. Similarly, the southeastern coast exhibited higher $\mathrm{Zn}$ concentrations $(\mathrm{K}-\mathrm{W}, \mathrm{p}<0.05)$ in the muscle tissues of the common octopus (Fig. 2).

Metal levels in the tissues of S. officinalis showed significant spatial variation as well. Concentrations were significantly higher in Bizerte and Monastir for Ag in the digestive gland 
$(\mathrm{K}-\mathrm{W}, \mathrm{p}<0.05)$ and for $\mathrm{Cu}$ and $\mathrm{Zn}$ in both digestive gland and arms $(\mathrm{K}-\mathrm{W}, \mathrm{p}<0.05)$. In contrast, cuttlefish from Sfax showed higher concentrations for $\mathrm{Cd}$ in both digestive gland and mantle (K-W, p<0.05), and equal or higher for Hg according to the tissue (Fig. 2).

\section{Interspecies comparison}

Considering all sites together, Kruskal-Wallis one-way analysis of variance indicated that trace element concentrations between species are most of the time significantly different ( $\mathrm{p}<0.05$; comparison by tissues and trace elements). However, no difference was observed for Cd concentrations comparing mantles of the 3 species $(\mathrm{p}=0.45)$. Multiple comparisons were then performed and highlighted some specific differences between species. Considering the digestive gland for instance, $O$. vulgaris showed the highest concentrations of $\mathrm{Ag}, \mathrm{Cd}$ and $\mathrm{Hg}$ among species $(\mathrm{K}-\mathrm{W}, \mathrm{p}<0.05)$; $\mathrm{Cu}$ and $\mathrm{Zn}$ concentrations were similar to S. officinalis and higher $(\mathrm{K}-\mathrm{W}, \mathrm{p}<0.05)$ than those of L. vulgaris. According to the multiple comparisons, $\mathrm{Cu}$ and $\mathrm{Zn}$ concentrations in the mantle were the highest in $O$. vulgaris compared to the other species $(\mathrm{K}-\mathrm{W}, \mathrm{p}<0.05)$ whereas $\mathrm{Hg}$ concentrations were significantly higher in squids than octopus $(\mathrm{K}-\mathrm{W}, \mathrm{p}<0.05)$. Finally, the common squid displayed the highest $(\mathrm{K}-\mathrm{W}, \mathrm{p}<0.05)$ levels for $\mathrm{Cd}$ and $\mathrm{Hg}$ in their arms compared to other investigated species whereas it presented the lowest $\mathrm{Cu}$ and $\mathrm{Zn}$ levels $(\mathrm{K}-\mathrm{W}, \mathrm{p}<0.05)$.

The Principal component analyses (PCA; integrating all the trace elements) were realized for each tissues (Figs. 3, 4, and 5). They showed a clear pattern of trace element concentrations for interspecies variation. Indeed, this analysis tore more or less species apart, especially for the digestive glands and arms (Figs. 3C and 4C). The first 2 principal components accounted for $74.44 \%$ of the variability in the metal concentrations in the digestive gland, with $52.54 \%$ on axis 1 and $21.90 \%$ on axis 2 (Fig. 3). Species were separated according to the axis 1 which clearly discriminated $O$. vulgaris and $L$. vulgaris relatively to the levels of $\mathrm{Ag}, \mathrm{Cd}, \mathrm{Cu}$ and $\mathrm{Zn}$. 
On the second axis, O. vulgaris and L. vulgaris were mainly distributed on the PCA according the relative levels of $\mathrm{Hg}$ (Fig. 3C).

In the arms, the PCA showed that the first two axes accounted $68.66 \%$ of variability, with $40.02 \%$ explained by axis 1 and $28.64 \%$ by axis 2 (Fig. 4). The first axis takes into account the relative levels of $\mathrm{Cd}$ and $\mathrm{Zn}$, while the second axis is correlated with the $\mathrm{Cu}$ and $\mathrm{Hg}$ levels. Squids were clearly discriminated according to their high $\mathrm{Hg}$ and $\mathrm{Cd}$ levels whereas octopus and cuttlefish, thight on this PCA, were differentiated from squids according to their $\mathrm{Cu}$ and Zn levels (Fig. 4C).

Figure 5 shows the PCA realized for the mantle. Axis 1 and 2 of the PCA here accounted for $65.08 \%$ of the variability in metal levels in the mantle between individuals, with $36.69 \%$ on axis 1 and $28.38 \%$ on axis 2 (Fig. 5). $\mathrm{Cu}$ and $\mathrm{Zn}$ strongly influenced variability between species along axis 1 whereas $\mathrm{Cd}$ and $\mathrm{Hg}$ concentrations contributed to axis 2. Species were not clearly separated in comparison to the 2 previous PCA perfomed on digestive gland and arms (Fig. 5C vs. Figs. 3C and 4C). Nevertheless, L. vulgaris seems to be related to elevetated concentrations of $\mathrm{Hg}$ and $\mathrm{Cd}$ as in arms.

Although the aim of these PCAs was to illustrate the interspecies comparison, the regroupment of samples through sampling location (Figs. 3D, 4D and 5D) complement our first approach showing, when metals are integrated through 2 components, the superposition of Sfax and Monastir profile and therefore the different profile of Bizerte. For instance, $\mathrm{Hg}$ seems the main driver of Bizerte profile (Figs. 3D, 4D and 5D).

\section{Effects of sex and size on metals accumulation}

Results of Generalized additive models (GAMs) fitted to the average log-transformed metal concentrations in the three selected tissues of $L$. vulgaris did not show any significant differences for $\mathrm{Ag}, \mathrm{Cd}$ and $\mathrm{Cu}$ concentrations considering sex and size. However, the GAMs 
established for $\mathrm{Hg}$ concentrations showed significant size effects, being negatively correlated with the body size (DML) in the digestive gland $(\mathrm{P}=0.015)$, mantle $(\mathrm{P}<0.01)$ and arms $(\mathrm{P}=0.018)$ (Figs. 6A, 6B and 6C). In contrast, a strong positive linear effect of DML $(\mathrm{P}<0.01)$ on $\mathrm{Hg}$ concentrations was detected in the mantle (Fig. 6D).

In the case of $O$. vulgaris, the effect of size was detected for $\mathrm{Cu}, \mathrm{Hg}$ and $\mathrm{Pb}$ concentrations: negative correlation was found between size and the digestive gland $(\mathrm{P}<0.01)$ and the mantle $(\mathrm{P}<0.001)$ for $\mathrm{Hg}$ (Figs. 7A and 7B), the digestive gland $(\mathrm{P}=0.049)$ for $\mathrm{Pb}($ Fig. $7 \mathrm{C})$ and in the arms ( $\mathrm{P}=0.027)$ for $\mathrm{Cu}($ Fig.7D). An effect of sex on which males showed significantly higher concentrations than females, was also found for $\mathrm{Hg}$ in the digestive gland $(\mathrm{p}=0.020)$, for $\mathrm{Hg}$ and $\mathrm{Cu}$ in the mantle $(\mathrm{P}=0.033$ and $\mathrm{P}=0.023$, respectively, and for $\mathrm{Zn}$ in the arms $(\mathrm{P}<0.01)$.

For S. officinalis, significant differences for size were included in the GAMs fitted for $\mathrm{Hg}$ and $\mathrm{Cu}$ concentrations. A linear positive correlation was detected between $\mathrm{Hg}$ levels and the body size in the digestive gland $(\mathrm{P}=0.021)$, the mantle $(\mathrm{P}<0.001)$ and the arms $(\mathrm{P}<0.01)$ (Figs. 8A, 8B and $8 \mathrm{C}$ ) whereas $\mathrm{Cu}$ concentration decreased with size ( $\mathrm{P}=0.011)$ (Fig. 8D). Considering the sex effect, males showed significantly lower $\mathrm{Hg}$ levels in the mantle $(\mathrm{P}=0.034)$ and the arms $(\mathrm{P}=0.035)$ than females.

\section{DISCUSSION}

Cephalopods are characterized by a strong ability to highly bioaccumulate trace elements in their tissues (Miramand and Bentley 1992; Bustamante et al., 1998b; Manso et al., 2007); the digestive gland appears to be the key organ, being deeply involved in the storage and/or detoxification of various essential and non essential metals of cephalopods (Bustamante et al., 2002a; Miramand et al., 2006; Raimundo et al., 2010). Since they are short-lived organisms, cephalopods are also interesting in reflecting the variation of metal concentrations in the 
environment where they live (Pierce et al., 2008). In the present study, the analysis of 6 metals ( $\mathrm{Ag}, \mathrm{Cd}, \mathrm{Cu}, \mathrm{Hg}, \mathrm{Pb}$ and $\mathrm{Zn}$ ) in edible tissues (muscles of both arms and mantle) and in the digestive gland of 3 major cephalopod species from Tunisia. It provides new dataset on an important seafood resources in the south Mediterranean Sea and it informs on the variation of contamination status along the entire tunisian coast.

\section{Comparison between species}

The analysis of metals in the three species (L. vulgaris, O. vulgaris and S. officinalis) with different lifestyle highlighted differences in their capacity of metal accumulation, each species consistently exhibiting different metal concentrations along the Tunisian coasts. For instance, the highest concentrations of $\mathrm{Ag}, \mathrm{Cd}, \mathrm{Cu}$ and $\mathrm{Zn}$ were found in octopuses and the lowest in squids from each locality. This result is in accordance with previous observations for the two same species in the Portuguese waters (Lourenço et al., 2009). Furthermore, Bustamante et al. 2002) showed that benthic cephalopods displayed significantly higher $\mathrm{Cd}, \mathrm{Cu}$ and $\mathrm{Zn}$ concentrations than pelagic ones, which could be explained by differences in their feeding behavior and their physiology. On the contrary, L. vulgaris showed the highest levels of $\mathrm{Hg}$ for all tissues in the northern coast, in both arms and mantle in the eastern coast and only in the arms in the southeastern coast. Food represents the main accumulation pathway for $\mathrm{Hg}$ in cephalopods (Lacoue-Labarthe et al., 2009b) but benthic cephalopods exhibit more complex diets than pelagic ones. Indeed, they feed on polychets, crustaceans, molluscs, echinoderms and fish (McQuaid, 1994) whereas squids mainly feed on fish and other cephalopod species (Pierce et al., 1994). In contrast to benthic prey, pelagic fish and cephalopods contain higher proportion of organic $\mathrm{Hg}$ (Bloom 1992; Bustamante et al., 2006b) which is more bioavailable than inorganic $\mathrm{Hg}$. Such a pelagic diet would lead to higher $\mathrm{Hg}$ exposure and therefore to 
higher $\mathrm{Hg}$ bioaccumulation in pelagic cephalopods since their prey contain higher organic $\mathrm{Hg}$ loads than those of benthic ones (Cossa et al., 1990).

\section{Metal distribution among tissues}

Highest concentrations of $\mathrm{Ag}, \mathrm{Cd}, \mathrm{Cu}, \mathrm{Pb}$ and $\mathrm{Zn}$ were found in the digestive gland of all species similarly to the same species from other locations (Miramand and Guary, 1980; Miramand and Bentley, 1992; Bustamante et al., 2002a; Bustamante et al., 2002b ; Nessim et al., 2003; Raimundo et al., 2004; Napoleão et al., 2005; Raimundo et al., 2005; Bustamante et al., 2008; Pereira et al., 2009). The intrinsic capacity of this organ to store these elements is likely related to its major role in the assimilation of trace metals and nutrients (Martin and Flegal 1975; Miramand and Bentley 1992 ; Bustamante et al., 2002a; Bustamante et al., 2006b; Lacoue-Labarthe et al., 2009a). Cephalopods are known for their high feeding rates and their elevated assimilation efficiencies to satisfy their fast growth rates. As a consequence of strong assimilation of essential and non essential metals, cephalopods evolved efficient detoxification processes in order to cope with their toxicity (Bustamante et al., 2002a). In this context, $\mathrm{Hg}$ generally appears to be an exception in the present study. $\mathrm{Hg}$ levels in the digestive gland of $L$. vulgaris and S. officinalis were generally similar than those measured in the muscle (both from arms and mantle), this result being consistent with previous works on squids from the Northern atlantic (Pierce et al., 2008) and from the Indian and Pacific oceans (Kojadinovic et al., 2011). In addition, Lacoue-Labarthe and coauthors (Lacoue-Labarthe et al., 2009b) reported that juvenile cuttlefish exposed to inorganic $\mathrm{Hg}$ via seawater accumulated mainly $\mathrm{Hg}$ in muscular parts (>70\%). However, the proportion of the whole body $\mathrm{Hg}$ content associated with the digestive gland increased during exposure and depuration phases, suggesting that the metal was detoxified from the muscles towards this organ. 
Our results confirmed that $\mathrm{Hg}$ organotropism in cephalopods differs according to the phylogeny (Sepiida and Teuthida vs Octopoda). Indeed, the digestive gland of the common octopus $O$. vulgaris displayed the highest $\mathrm{Hg}$ concentrations among the three tissues, which contrasts with L. vulgaris and S. officinalis. It is also consistent with previous works on different octopus species along the European coasts (Raimundo et al., 2004; Seixas et al., 2005; Bustamante et al., 2006a) that reported elevated $\mathrm{Hg}$ concentrations in ocopus. The preferential concentration of $\mathrm{Hg}$ in digestive gland of $O$. vulgaris might be related to different Hg uptake pathway in $O$. vulgaris compared to the other species and most probably a higher contribution of food pathway to global upake or a higher retention of $\mathrm{Hg}$ from octopuses than the others (Bustamante et al. 2006).

\section{Accumulation differences between sites}

As mentioned previously, cephalopods are short-lived species and thus they are supposed to reflect short-term ambient concentrations of metals in the surrounding environment (Bustamante et al., 2008; Pierce et al., 2008). Due to the low metal concentrations found in the muscle tissues and their low variability of all species, the digestive gland was used to compare the $\mathrm{Ag}, \mathrm{Cu}, \mathrm{Cd}, \mathrm{Pb}$ and $\mathrm{Zn}$ concentrations between sampling sites. Geographical variation of metal concentrations was not similar for all the species: concentrations of $\mathrm{Ag}$ and $\mathrm{Pb}$ found in cuttelfish and octopus were significatly higher in the northern (Bizerte) and eastern (Monastir) coasts than in the southeastern (Sfax). Interestingly, $\mathrm{Ag}$ and $\mathrm{Pb}$ concentrations did not vary in squids, which can be related the difference in diet but aslo the different habitats. Squids are neritic and/or oceanic cephalopods eaten mainly on fish whereas octopuses and cuttlefishes are more benthic cephalopods (closer to the coast) feeding most of the time on bottom invertebrates such crustaceans, bivalves and polychetes (Boyle, 1990; McQuaid, 1994). A previous study conducted along the Tunisian coast on algae showed that 
the highest concentration of $\mathrm{Pb}$ was observed in Bizerte; important industrial releases, the sewage wastes, harbors and the ferry traffic in Bizerte could be the source (El Ati-Hellal et al., 2005). A similar geographical trend was observerd for the $\mathrm{Cu}$ concentrations in cuttlefish and $\mathrm{Zn}$ concentrations in both squids and cuttlefish. This variation of $\mathrm{Cu}$ and $\mathrm{Zn}$ in the digestive gland is difficult to confront with the environmental data due to the lack of reliable measurements. However, the uniform concentrations of $\mathrm{Zn}$ in octopuses and $\mathrm{Cu}$ in squids and octopuses captured along the Tunisian coast may be explained by metabolic functions such as homeostatic mechanisms that regulate these levels in the organism (Canli et al., 2001).

Cd behavior was distincted from the other metals, especially in the case Cd concentrations in octopus and cuttlefishes from southeastern coast: they were higher than the $\mathrm{Cd}$ concentrations from the northern and eastern coasts. This could be related to the higher level of $\mathrm{Cd}$ in the coastal waters of Sfax subjected to the continuous discharge of metals from local industrial activities and from the phosphogypsum stock (Hamza-Chaffai et al., 1997). Several reports indicated the contaminated status of the coast, especially by Cd (Hamza-Chaffai et al., 2003; Smaoui-Damak et al., 2003; Banni et al., 2005; Banni et al., 2007). Thus, high Cd concentrations have been previously measured in other marine organisms collected in this area such as the clam Ruditapes decussates (Hamza-Chaffai et al., 2003; Smaoui-Damak et al., 2003) and the scorpionfish Scorpaena porcus (Hamza-Chaffai et al., 1995). In addition, the higher Cd concentrations in the muscle from arms and mantle in Sfax indicate that the sequestration capacity of the digestive gland was exceeded and resulted in a transfer of the metal toward muscle tissues. This Cd transfer from digestive glands to edible tissues and the impact of increased Cd contamination coul lead to a food safety problem of the human consumer in this highly Cd contaminated area.

Geographical variations were also observed for $\mathrm{Hg}$ concentrations in the digestive gland and the muscle. Clearly, specimens captured in the northern and the eastern coasts exhibited 
higher levels of $\mathrm{Hg}$ in all tissue than those from the south. A similar pattern has been shown in small pelagic fish in this areas (Joiris et al., 1999). Eastern sites may be subjected to potential natural inputs from nearby $\mathrm{Hg}$ ferous belts and previous mining areas (Joiris et al., 1999). Additionally, there is a high industrial activities along the Italian coast, Italy facing Tunisia.

\section{Influence of biological parameters}

The potential impact of length (dorsal mantle length; DML) and sex have been preliminary considered here, the "preliminary" character need to be emphasized given the limited number of samples to draw a conclusion but at least it gave us a hint of potential biological parameters in these cephalopods caught in North Africa. Considering all tissues in all species, metal concentrations did not show significant differences between males and females except for few cases. In $O$. vulgaris, males showed always significant higher values than females for $\mathrm{Hg}$ concentrations in the digestive gland and mantle, $\mathrm{Cu}$ concentrations in the mantle and $\mathrm{Zn}$ concentrations in the arms. On contrary, females presented the highest $\mathrm{Hg}$ concentrations in the muscle (mantle and arms) of S. officinalis. This is probably due to the existence of physiological and/ or ecological inter-sex differences (Monteiro et al., 1992) such as different behaviour (Jozet-Alves et al., 2008), sexual dimorphism for some species (Jackson et al., 2007) or maternal transfer/elimination of metals through eggs (showed in cuttlefish; LacoueLabarthe et al., 2008). A previous study on cephalopods provides conflicting results in terms of metal concentrations and sex: thus $O$. vulgaris from the East Mediterranean coast showed higher $\mathrm{Cd}$ and $\mathrm{Cu}$ concentrations in mantle tissue in female than male (Nessim et al., 2003). Additionally, (Ayas and Ozogul, 2011) described such influence of gender for $\mathrm{Cd}, \mathrm{Cu}, \mathrm{Pb}$ and Zn levels in the mantle of S. officinalis from the Turkish waters. However, other works on cephalopods (Miramand and Bentley, 1992;; Barghigiani et al., 2000; Kojadinovic et al., 2011) reported the lack of relation between heavy metals concentrations and sex. 
Results from different correlations estimated between heavy metal concentrations in tissues of different species and size (viz. mantle length) showed significant negative relationships for $\mathrm{Hg}$ in all tissues of L. vulgaris, for $\mathrm{Hg}$ and $\mathrm{Pb}$ in the digestive gland, $\mathrm{Hg}$ in the mantle and $\mathrm{Cu}$ in the arms in $O$. vulgaris and for $\mathrm{Cu}$ in the mantle in S. officinalis. The negative relationships between heavy metal concntrations in the tissues and cephalopods sizes are consistent with previous studies: Cd concentrations decreased with length in the squid L. forbesi from the European waters (Pierce et al., 2008) as well as for Octopus salutii and Eledone cirrhosa from the Mediterranean Sea (Barghigiani et al., 1993; Storelli and Marcotrigiano, 1999). A plausible explanation for the negative correlations between these metals and cephalopods size could be attributed to the existence of a «dilution» effect linked to the rapid increase of tissue mass due to growth (that is very rapid in cephalopods) with regards to proportionally lower intake of trace elements (Pierce et al., 2008). On the contrary to the above results, $\mathrm{Hg}$ concentrations were positively correlated with size in all tissues of S. officinalis. This result is an agreement with observations described for the same metal in Eledone cirrhosa (Rossi etal. 1993), in loliginid squid (Bustamante et al. 2006; Pierce et al., 2008) and in cuttlefish (Chouvelon et al. 2011). The discrepancy of these observations resulted probably from the more prominent effect of different factors, such as food availability (i.e., quality and quantity of food) and growth rates (which may be affected by temperature) (Villanueva et al., 2002), on the metal accumulation in cephalopods.

\section{CONCLUSION}

The present work provides new information on bioaccumulation and tissue distribution of 6 heavy metals in three species (O. vulgaris, L. vulgaris and $S$. officinalis) from the Tunisian waters. Among the major information provided in the present work, which by the way represents a first investigation in North Africa, we confirmed the important role of digestive 
gland and the variation of $\mathrm{Hg}$ organotropisms among species. It also keep the debate ongoing concerning the effect of sex and lengths on metal concentrations in cephalopods. In addition, metal concentrations measured in the edible tissues indicated that for elevated consumption of flesh, toxic risk may be reached for $\mathrm{Cd}$ in all the species collected in contaminated areas and for $\mathrm{Hg}$ in squid and cuttlefish. Evaluation of this risk deserves further investigations.

Acknowledgments: MR benefits from a PhD fellowship provided by the Tunisian Ministery of Higher Education and Scientific Resarch. MM is Nippon Foundation Senior Nereus Fellow at the Stockholm Resilience Centre. We are grateful to C. Churlaud for her help in the $\mathrm{Hg}$ analyses. This study has been financially supported by the laboratory LIENSs and the CPER (Contrat de Projet Etat Région).

\section{REFERENCES}

Ayas, D., Ozogul, Y. (2011) The Effects of Season and Sex in the Metal Levels of Mature Common Cuttlefish (Sepia officinalis) in Mersin Bay, Northeastern Mediterranean. Journal of Food Science, 76, 121-124.

Banni, M., Dondero, F., Jebali, J., Guerbej, H., Boussetta, H., Viarengo, A. (2007) Assessment of heavy metal contamination using real-time PCR analysis of mussel metallothionein $\mathrm{mt} 10$ and $\mathrm{mt} 20$ expression: a validation along the Tunisian coast. Biomarkers, 12, 369-83.

Banni, M., Jebali, J., Daubeze, M., Clerandau, C., Guerbej, H., Narbonne, JF., et al. (2005) Monitoring pollution in Tunisian coasts: application of a classification scale based on biochemical markers. Biomarkers, 10, 105-16.

Barghigiani C, D'Ulivo A, Zamboni R, Lampugnani L. Interaction between selenium and cadmium in Eledone cirrhosa of the northern Tyrrhenian Sea. Marine Pollution Bulletin 1993; 26: 212-216.

Barghigiani C, Ristori T, Biagi F, De Ranieri S. Size Related Mercury Accumulations in Edible Marine Species from an Area of the Northern Tyrrhenian Sea. Water, Air, and Soil Pollution 2000; 124: 169-176.

Bloom, N.S. (1992) On the chemical form of mercury in edible fish and marine invertebrate tissue. Canadian Journal of Fisheries and Aquatic Sciences, 49, 1010-1017.

Boujelben, B. (1998) Dosage de métaux lourds (Plomb, Cadmium, Cuivre, Zinc) dans les poissons péchés dans la région de Sfax. Doctorat en médecine vétérinaire. Faculté de médecine vétérinaire de Sidi Thabet. 79 pp.

Boyle, P.R. (1990) Cephalopod biology in the fisheries context. Fisheries Research 8, 303321.Boyle, P., Rodhouse, P. (2005) Cephalopods: Ecology and Fisheries: Blackwell Publishing, Oxford. 
Bustamante, P., Caurant, F., Fowler, S.W., Miramand, P. (1998a) Cephalopods as a vector for the transfer of cadmium to top marine predators in the north-east Atlantic Ocean. Science of The Total Environment, 220, 71-80.

Bustamante, P., Cherel, Y., Caurant, F., Miramand, P. (1998b) Cadmium, copper and zinc in octopuses from Kerguelen Islands, Southern Indian Ocean. Polar Biology, 19, 264271.

Bustamante, P., Cosson, R.P., Gallien, I., Caurant, F., Miramand, P. (2002a) Cadmium detoxification processes in the digestive gland of cephalopods in relation to accumulated cadmium concentrations. Marine Environmental Research, 53, 227-241.

Bustamante, P., Teyssié, JL., Fowler, S.W., Cotret, O., Danis, B., Miramand, P., Warnau, M. (2002b) Biokinetics of zinc and cadmium accumulation and depuration at different stages in the life cycle of the cuttlefish Sepia officinalis. Marine Ecology-Progress Series, 231, 167-177.

Bustamante, P., Lahaye, V., Durnez, C., Churlaud, C., Caurant, F. (2006a) Total and organic $\mathrm{Hg}$ concentrations in cephalopods from the North Eastern Atlantic waters: Influence of geographical origin and feeding ecology. Science of The Total Environment, 368, 585-596.

Bustamante, P., Bertrand, M., Boucaud-Camou, E., Miramand, P. (2006b) Subcellular distribution of $\mathrm{Ag}, \mathrm{Cd}, \mathrm{Co}, \mathrm{Cu}, \mathrm{Fe}, \mathrm{Mn}, \mathrm{Pb}$, and $\mathrm{Zn}$ in the digestive gland of the common cuttlefish Sepia officinalis. Journal of Shellfish Research, 25, 987-993.

Bustamante, P., Gonzalez A, Rocha F, Miramand P, Guerra A. (2008) Metal and metalloid concentrations in the giant squid Architeuthis dux from Iberian waters. Marine Environmental Research, 66, 278-287.

Canli M, Kalay M, Ay Ö. (2001) Metal (Cd, Pb, Cu, Zn, Fe, Cr, Ni) Concentrations in Tissues of a Fish Sardina pilchardus and a Prawn Peaenus japonicus from Three Stations on the Mediterranean Sea. Bulletin of Environmental Contamination and Toxicology, 67, 75-82.

Chouvelon, T., Spitz, J., Cherel, Y., Caurant, F., Sirmel, R., Mendez-Fernandez, P., Bustamante, P. (2011) Inter-specific and ontogenic differences in $\delta^{13} \mathrm{C}$ and $\delta^{15} \mathrm{~N}$ values and $\mathrm{Hg}$ and $\mathrm{Cd}$ concentrations in cephalopods. Marine Ecology-Progress Series 433, 107-120.

CGP. (1996) Annuaire des statistiques des pêches en Tunisie. Ministère de l'agriculture, Tunisie.

Cossa D, Thibaud Y, Roméo M, Gnassia-Barelli M. (1990) Le mercure en milieu marin. Biogéochimie et écotoxicologie. Rapport scientifiques et techniques de l'IFREMER, Brest.

Dorneles PR, Lailson-Brito J, dos Santos RA, Silva da Costa PA, Malm O, Azevedo AF, et al. (2007) Cephalopods and cetaceans as indicators of offshore bioavailability of cadmium off Central South Brazil Bight. Environmental Pollution, 148, 352-359.

El Ati-Hellal M, Hedhili A, Hellal F, Boujlel K, Dachraoui M, Bousnina M, et al. (2005) Lead and cadmium concentrations in seawater and algae of the tunisian coast. Vol 82. Tunis, TUNISIE: Institut Pasteur de Tunis.

FAO (2007) Fisheries and Aquaculture Information and Statistics Service, Fisheries commodities production and trade 1976-2005. Food and Agriculture Organization of the United Nations, FISHSTAT Plus - Universal software for fishery statistical time series [online or CD-ROM]. Available at: http://www.fao.org/fi/statist/FISOFT/FISHPLUS.asp.

Hamza-Chaffai A, Amiard-Triquet C, El Abed A. (1997) Metallothionein-Like Protein: Is It an Efficient Biomarker of Metal Contamination? A Case Study Based on Fish From 
the Tunisian Coast. Archives of Environmental Contamination and Toxicology, 33, 53-62.

Hamza-Chaffai A, Cosson RP, Amiard-Triquet C, El Abed A. (1995) Physico-chemical forms of storage of metals $(\mathrm{Cd}, \mathrm{Cu}$ and $\mathrm{Zn})$ and metallothionein-like proteins in gills and liver of marine fish from the Tunisian coast: ecotoxicological consequences. Comparative Biochemistry and Physiology Part C: Pharmacology, Toxicology and Endocrinology, 111, 329-341.

Hamza-Chaffai A, Pellerin J, Amiard JC. (2003) Health assessment of a marine bivalve Ruditapes decussatus from the Gulf of Gabès (Tunisia). Environment International, 28, 609-617.

Jebali J, Banni M, de Almeida EA, Boussetta H. (2007) Oxidative DNA damage levels and catalase activity in the clam Ruditapes decussatus as pollution biomarkers of Tunisian marine environment. Environmental Monitoring Assessment, 124, 195-200.

Jackson G, Wotherspoon S, Jackson C. (2007) Temporal life history plasticity of the Southern Ocean squid Todarodes filippovae from waters off Tasmania, Australia. Marine Biology, 150, 575-584.

Joiris CR, Holsbeek L, Moatmeri NL. (1999) Total and Methylmercury in Sardines Sardinella aurita and Sardina pilchardus from Tunisia. Marine Pollution Bulletin, 38, 188-192.

Jozet-Alves C, Modéran J, Dickel L. (2008) Sex differences in spatial cognition in an invertebrate: The cuttlefish. Proceedings of the Royal Society B: Biological Sciences, 275, 2049-2054.

Kojadinovic J, Jackson CH, Cherel Y, Jackson GD, Bustamante P. (2011) Multi-elemental concentrations in the tissues of the oceanic squid Todarodes filippovae from Tasmania and the southern Indian Ocean. Ecotoxicology Environmental Safety, 74, 1238-49.

Lacoue-Labarthe T, Warnau M, Oberhänsli F, Teyssié J-L, Jeffree R, Bustamante P. (2008) First experiments on the maternal transfer of metals in the cuttlefish Sepia officinalis. Marine Pollution Bulletin, 57, 826-831.

Lacoue-Labarthe T, Martin S, Oberhansli F, Teyssie JL, Markich S, Ross J, et al. (2009a) Effects of increased $\mathrm{pCO}(2)$ and temperature on trace element $(\mathrm{Ag}, \mathrm{Cd}$ and $\mathrm{Zn}$ ) bioaccumulation in the eggs of the common cuttlefish, Sepia officinalis. Biogeosciences, 6, 2561-2573.

Lacoue-Labarthe T, Warnau M, Oberhänsli F, Teyssié J-L, Bustamante P. (2009b) Bioaccumulation of inorganic $\mathrm{Hg}$ by the juvenile cuttlefish Sepia officinalis exposed to ${ }^{203} \mathrm{Hg}$ radiolabelled seawater and food. Aquatic Biology, 6, 91-98.

Lourenço HM, Anacleto P, Afonso C, Ferraria V, Martins MF, Carvalho ML, et al. (2009) Elemental composition of cephalopods from Portuguese continental waters. Food Chemistry, 113, 1146-1153.

Manso M, Carvalho ML, Nunes ML. (2007) Characterization of essential and toxic elements in cephalopod tissues by EDXRF and AAS. X-Ray Spectrometry, 36, 413-418.

Martin, J.H., Flegal, A.R. (1975) High copper concentrations in squid livers in association with elevated levels of silver, cadmium, and zinc. Marine Biology 30, 51-55.

McQuaid CD. (1994) Feeding behaviour and selection of bivalve prey by Octopus vulgaris Cuvier. Journal of Experimental Marine Biology and Ecology, 177, 187-202.

Metian M, Warnau M, Chouvelon T, Pedraza F, Rodriguez y Baena AM, Bustamante P. (2013) Trace element bioaccumulation in reef fish from New Caledonia: Influence of trophic groups and risk assessment for consumers. Marine Environmental Research, 87-88C: 26-36.

Miramand P, Bentley D. (1992) Concentration and distribution of heavy metals in tissues of two cephalopods, Eledone cirrhosa and Sepia officinalis, from the French coast of the English Channel. Marine Biology, 114, 407-414. 
Miramand P, Bustamante P, Bentley D, Kouéta N. (2006) Variation of heavy metal concentrations ( $\mathrm{Ag}, \mathrm{Cd}, \mathrm{Co}, \mathrm{Cu}, \mathrm{Fe}, \mathrm{Pb}, \mathrm{V}$, and $\mathrm{Zn}$ ) during the life cycle of the common cuttlefish Sepia officinalis. Science of The Total Environment, 361, 132-143.

Miramand P, Guary JC. (1980) High concentrations of some heavy metals in tissues of the Mediterranean octopus. Bulletin of Environmental Contamination and Toxicology, 24, 783-788.

Monteiro LR, Porteiro FM, Gonçalves JM. (1992) Inter- and intra-specific variation of mercury levels in muscle of cephalopods from the Azores. Arquipélago, 10, 13-22.

Napoleão P, Pinheiro T, Sousa Reis C. (2005) Elemental characterization of tissues of Octopus vulgaris along the Portuguese coast. Science of The Total Environment, 345, 41-49.

Nessim, Ramzy B, Riad, Rafik G. (2003) Bioaccumulation of heavy metals in Octopus vulgaris from coastal waters of Alexandria (Eastern Mediterranean). 19. Taylor \& Francis, Abingdon, UK, pp. 7.

Pereira P, Raimundo J, Vale C, Kadar E. (2009) Metal concentrations in digestive gland and mantle of Sepia officinalis from two coastal lagoons of Portugal. Science of The Total Environment, 407, 1080-8.

Piatkowski U, Pierce GJ, Morais da Cunha M. (2001) Impact of cephalopods in the food chain and their interaction with the environment and fisheries: an overview. Fisheries Research, 52, 5-10.

Pierce GJ, Boyle PR, Hastie LC, Santos MB. (1994) Diets of squid Loligo forbesi and Loligo vulgaris in the northeast Atlantic. Fisheries Research, 21, 149-163.

Pierce GJ, Stowasser G, Hastie LC, Bustamante P. (2008) Geographic, seasonal and ontogenetic variation in cadmium and mercury concentrations in squid (Cephalopoda: Teuthoidea) from UK waters. Ecotoxicology and Environmental Safety, 70, 422-432.

R Development Core Team. (2010) R: a language and environment for statistical computing. R Foundation for Statistical Computing, Vienna, www.R-project.org.

Raimundo J, Caetano M, Vale C. (2004) Geographical variation and partition of metals in tissues of Octopus vulgaris along the Portuguese coast. Science of The Total Environment, 325, 71-81.

Raimundo J, Costa PM, Vale C, Costa MH, Moura I. (2010) Metallothioneins and trace elements in digestive gland, gills, kidney and gonads of Octopus vulgaris. Comparative Biochemistry and Physiology C, 152, 139-46.

Raimundo J, Pereira P, Vale C, Caetano M. (2005) Fe, $\mathrm{Zn}, \mathrm{Cu}$ and Cd concentrations in the digestive gland and muscle tissues of Octopus vulgaris and Sepia officinalis from two coastal areas in Portugal. Ciencias Marinas, 31, 243-251.

Renzoni A, Bacci E, Falciai L. (1973) Mercury concentration in the water, sediments and fauna of an area of the Tyrrhenian coast. Revue Internationale Océanographie. Méditerannée 31-32.

Rossi A, Pellegrini D, Belcari P, Barghigiani C. (1993) Mercury in Eledone cirrhosa from the Northern Tyrrhenian Sea: Contents and relations with life cycle. Marine Pollution Bulletin, 26, 683-686.

Seixas S, Bustamante P, Pierce G. (2005) Accumulation of mercury in the tissues of the common octopus Octopus vulgaris (L.) in two localities on the Portuguese coast. Science of The Total Environment, 340, 113-22.

Smaoui-Damak W, Hamza-Chaffai A, Berthet B, Amiard JC. (2003) Preliminary study of the clam Ruditapes decussatus exposed in situ to metal contamination and originating from the Gulf of Gabès, Tunisia. Bulletin of Environmental Contamination and Toxicology, 71, 961-970. 
Stoepler M, Berhnard M, Backhaus F, Schulte E. (1979) Comparative studies on trace metal levels in marine biota: I. Mercury in marine organisms from Western Italian coast, the Strait of Gibraltar and the North Sea. Science of the Total Environment, 13, 209-223.

Storelli MM, Marcotrigiano GO. (1999) Cadmium and total mercury in some cephalopods from the South Adriatic Sea (Italy). Food Additives and Contaminants, 16, 261-265.

Villanueva R, Koueta N, Riba J, Boucaud-Camou E. (2002) Growth and proteolytic activity of Octopus vulgaris paralarvae with different food rations during first feeding, using Artemia nauplii and compound diets. Aquaculture, 205, 269-286.

Zuur AF, Ieno EN, Smith GM. (2007) Analysing Ecological Data. New York: Springer. 
Table 1: Biological measurements obtained for the cephalopod samples. N: number of individuals; DML: Dorsal mantle length.

\begin{tabular}{|c|c|c|c|c|c|c|c|c|}
\hline \multirow[t]{2}{*}{ Species } & \multirow[t]{2}{*}{ Site } & \multirow[t]{2}{*}{$\mathbf{N}$} & \multirow[t]{2}{*}{ Sex } & \multirow{2}{*}{$\begin{array}{l}\text { Maturity } \\
\text { stage }\end{array}$} & \multicolumn{2}{|l|}{ DML (mm) } & \multicolumn{2}{|l|}{ Weight (g) } \\
\hline & & & & & Mean \pm SD & Range & Mean \pm SD & Range \\
\hline \multirow[t]{3}{*}{ L. vulgaris } & Bizerte & 4 & $4+$ & III & $196 \pm 29$ & $167-227$ & $220 \pm 81$ & $145-318$ \\
\hline & Monastir & 10 & $7 \lesssim ; 3$ & III, II & $188 \pm 21$ & $162-225$ & $130 \pm 23$ & $97-157$ \\
\hline & Sfax & 10 & 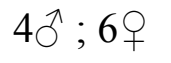 & III, II & $213 \pm 20$ & $190-256$ & $220 \pm 36$ & 184- 297 \\
\hline \multirow[t]{3}{*}{ O. vulgaris } & Bizerte & 7 & 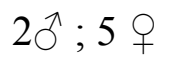 & III, II & $116 \pm 18$ & $98-150$ & $623 \pm 348$ & $343-1267$ \\
\hline & Monastir & 5 & $3 \widehat{\jmath} ; 2$; & III, II & $126 \pm 20$ & $112-160$ & $746 \pm 143$ & 624- 983 \\
\hline & Sfax & 8 & 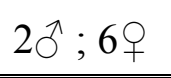 & III, II & $133 \pm 16$ & $113-155$ & $851 \pm 157$ & 607- 1033 \\
\hline \multirow[t]{3}{*}{ S. officinalis } & Bizerte & 7 & $10^{\pi} ; 6$ 우 & III & $119 \pm 16$ & $97-140$ & $208 \pm 79$ & $105-328$ \\
\hline & Monastir & 10 & $8 \widehat{1} ; 29$ & III & $119 \pm 11$ & $103-135$ & $186 \pm 47$ & $117-258$ \\
\hline & Sfax & 10 & $4 \widehat{\bigcirc} ; 6$ 平 & III, II, I & $99 \pm 20$ & $65-130$ & $136 \pm 66$ & $41-248$ \\
\hline
\end{tabular}


Table 2: Comparison of metal concentrations $\left(\mu \mathrm{g} \cdot \mathrm{g}^{-1} \mathrm{~d} . \mathrm{w}\right)$ of certified reference materials from the NRCC determined in the present study with certified values.

\begin{tabular}{lllllll}
\hline \hline Metal & TORT-2 $(\mathbf{n = 6})$ & & DOLT-4 $(\mathbf{n = 3})$ & \multicolumn{3}{c}{ DORM-2 $(\mathbf{n = 4})$} \\
\hline & Certified values & Present study & Certified values & Present study & Certified values & Present study \\
\hline $\mathbf{Z n}$ & $180 \pm 6$ & $170 \pm 12$ & - & & $25.3 \pm 2.3$ & $23.5 \pm 0.7$ \\
$\mathbf{C u}$ & $106 \pm 10$ & $98 \pm 10$ & - & - & $2.34 \pm 0.16$ & $2.29 \pm 0.18$ \\
$\mathbf{C d}$ & $26.7 \pm 0.6$ & $25.62 \pm 1.82$ & - & - & $0.043 \pm 0.008$ & $0.042 \pm 0.016$ \\
$\mathbf{P b}$ & $0.35 \pm 0.13$ & $0.43 \pm 0.27$ & - & - & - & - \\
$\mathbf{A g}$ & - & - & $0.93 \pm 0.07$ & $0.85 \pm 0.01$ & - & - \\
$\mathbf{H g}$ & $0.27 \pm 0.06$ & $0.26 \pm 0.03$ & $2.58 \pm 0.22$ & $2.54 \pm 0.18$ & - & - \\
\hline \hline
\end{tabular}




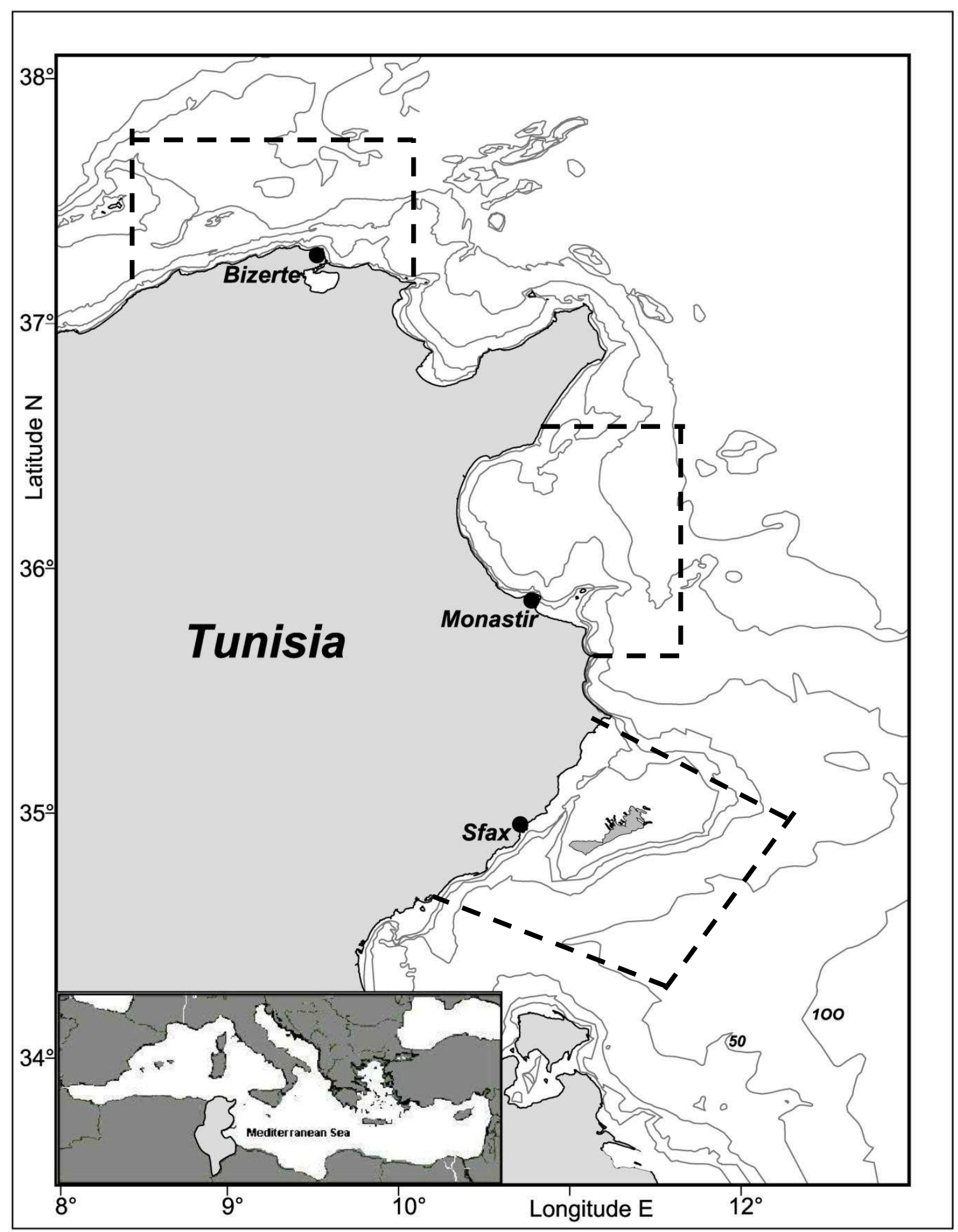

Figure 1: Sampling locations (Bizerte, Monastir and Sfax) along the Tunisian coast. 


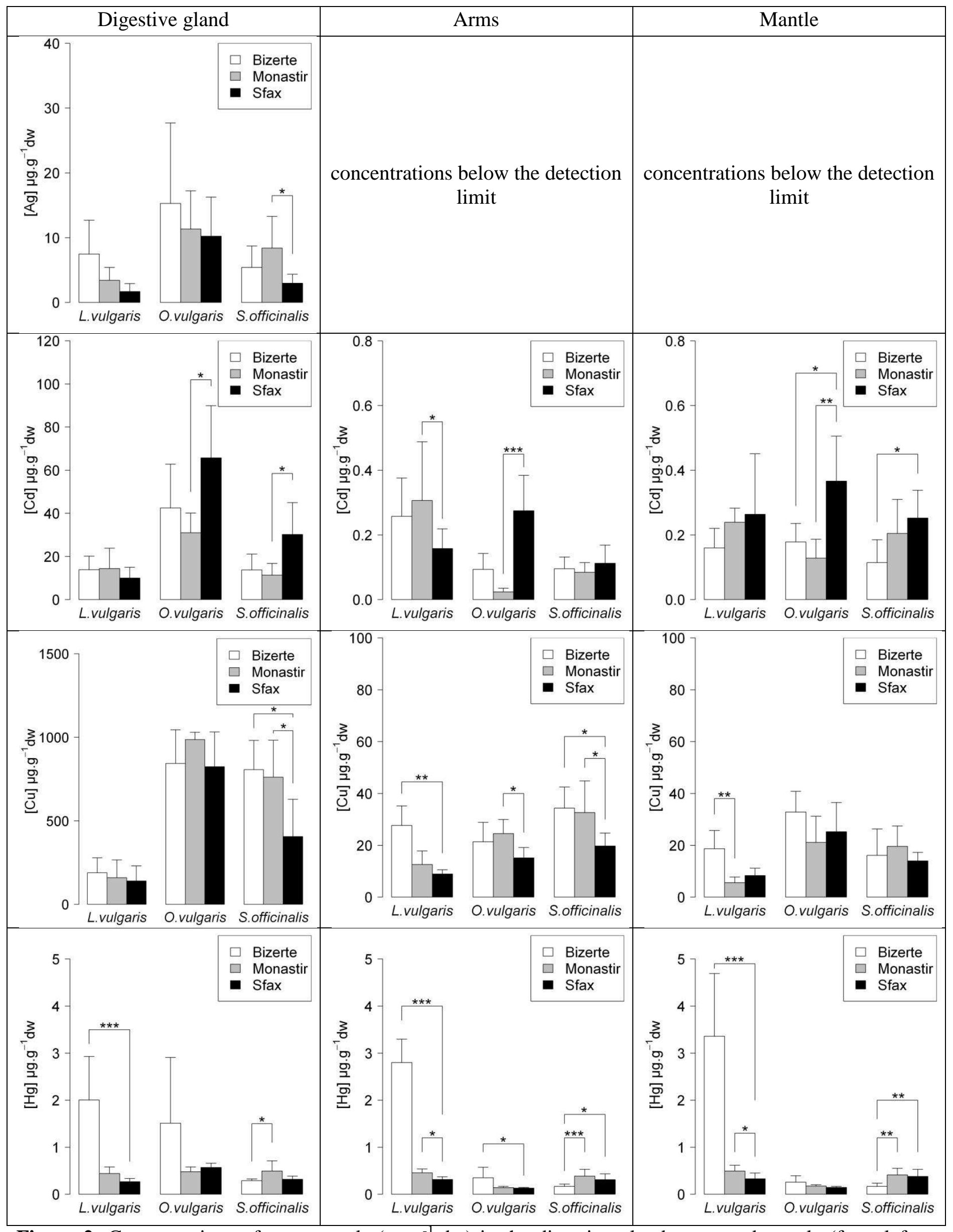

Figure 2: Concentrations of trace metals $\left(\mu \mathrm{g} \cdot \mathrm{g}^{-1} \mathrm{dw}\right.$ ) in the digestive gland, arms and mantle (from left to right) of L. vulgaris, O. vulgaris and S. officinalis from Bizerte, Monastir and Sfax. To assess whether the differences between locations were significant Kruskal-Wallis test followed by a multiple comparison test with Holm adjustment method was performed. Significant differences: ${ }^{*}$ for $p<0.05 ;{ }^{* * *}$ for $p<0.01$; ${ }^{* * *}$ for $p<0.001$. 


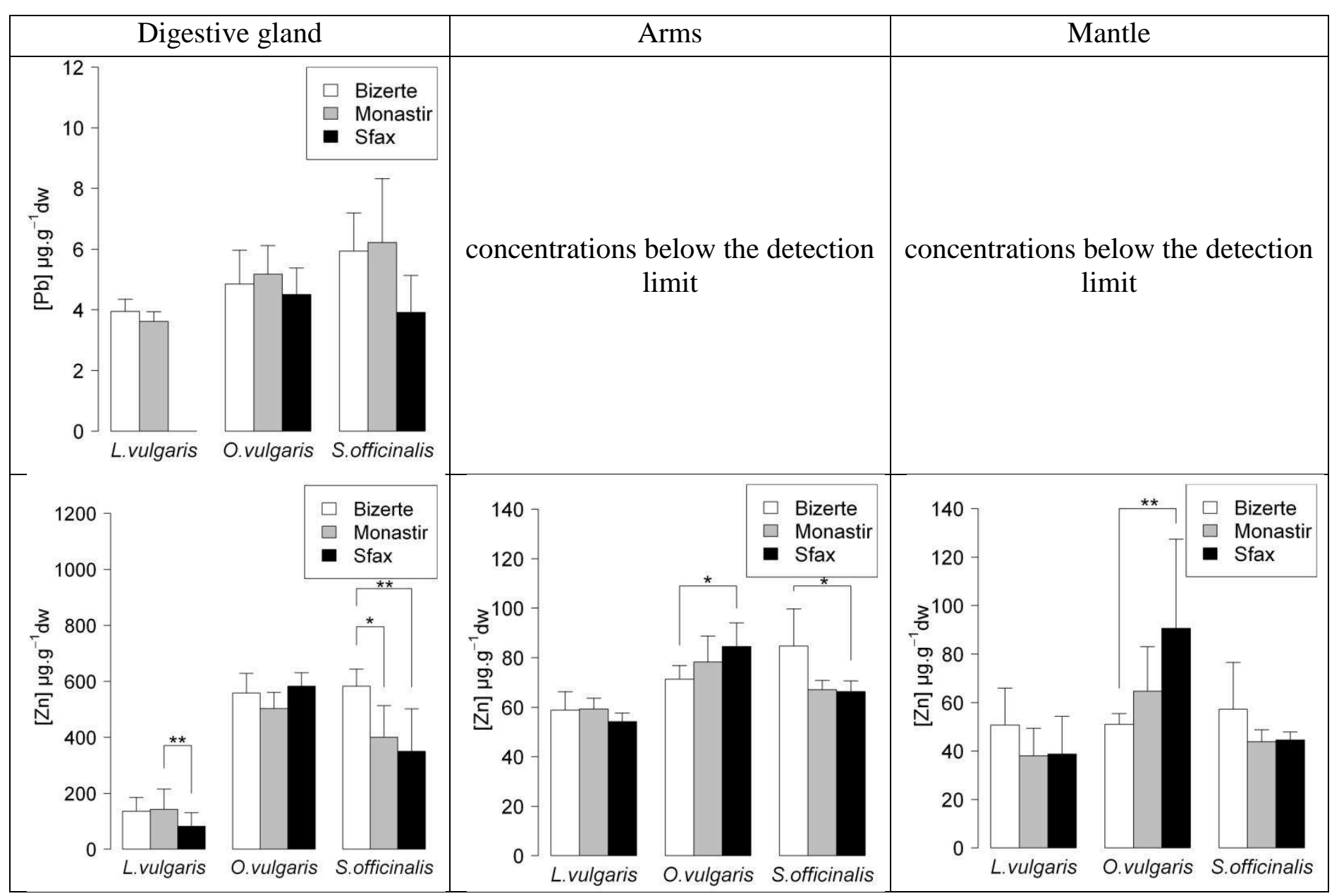

Figure 2 (continued) 


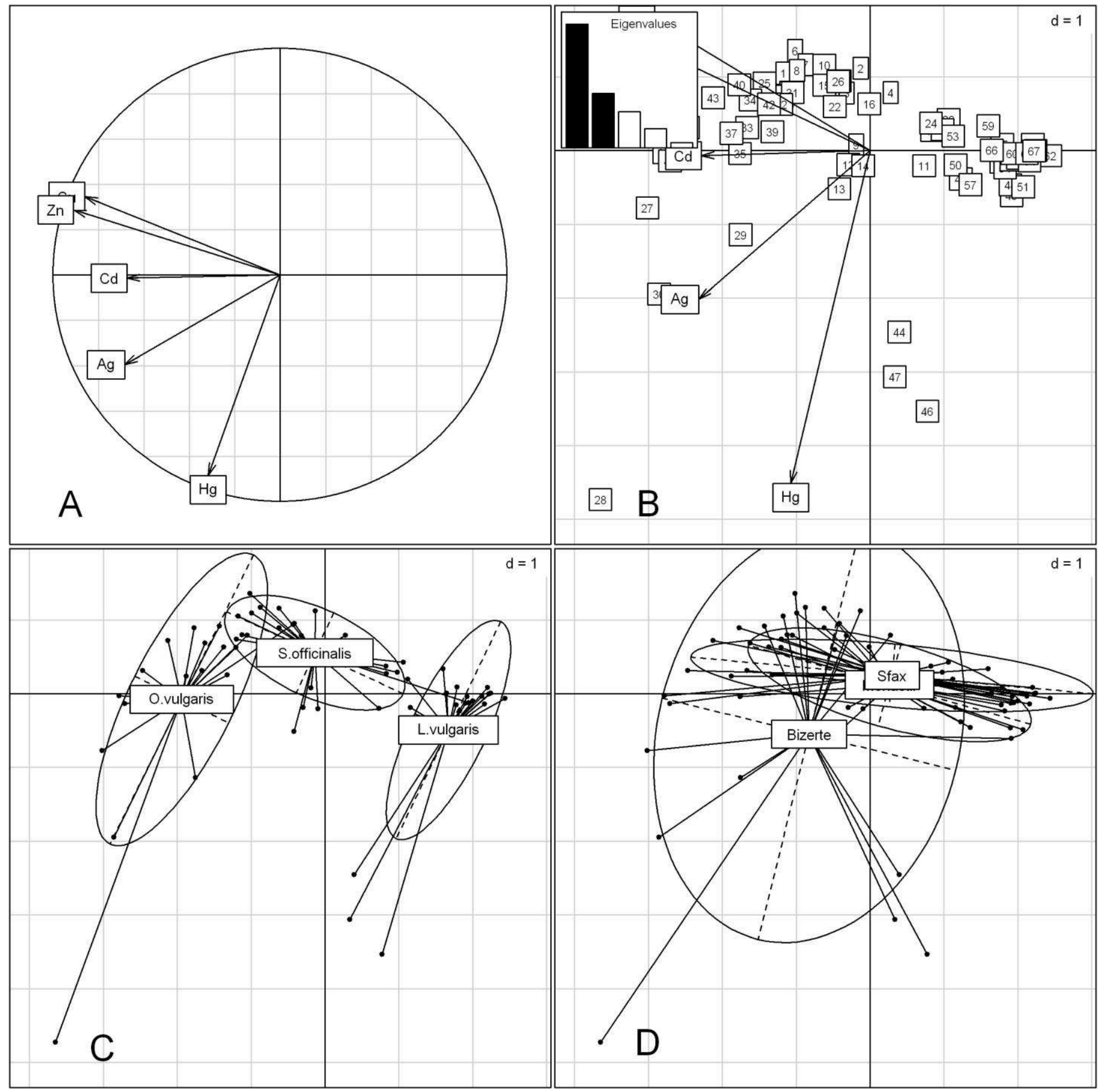

Figure 3: Principal component analysis (PCA) of cephalopods based on metal levels in the digestive gland. A) Correlation bi-plot showing the distribution of the variables. B) Projection of individuals on the correlation bi-plot with eigenvalue of the first two components. C) Grouping individuals by species. D) Grouping individuals by sampling sites. 


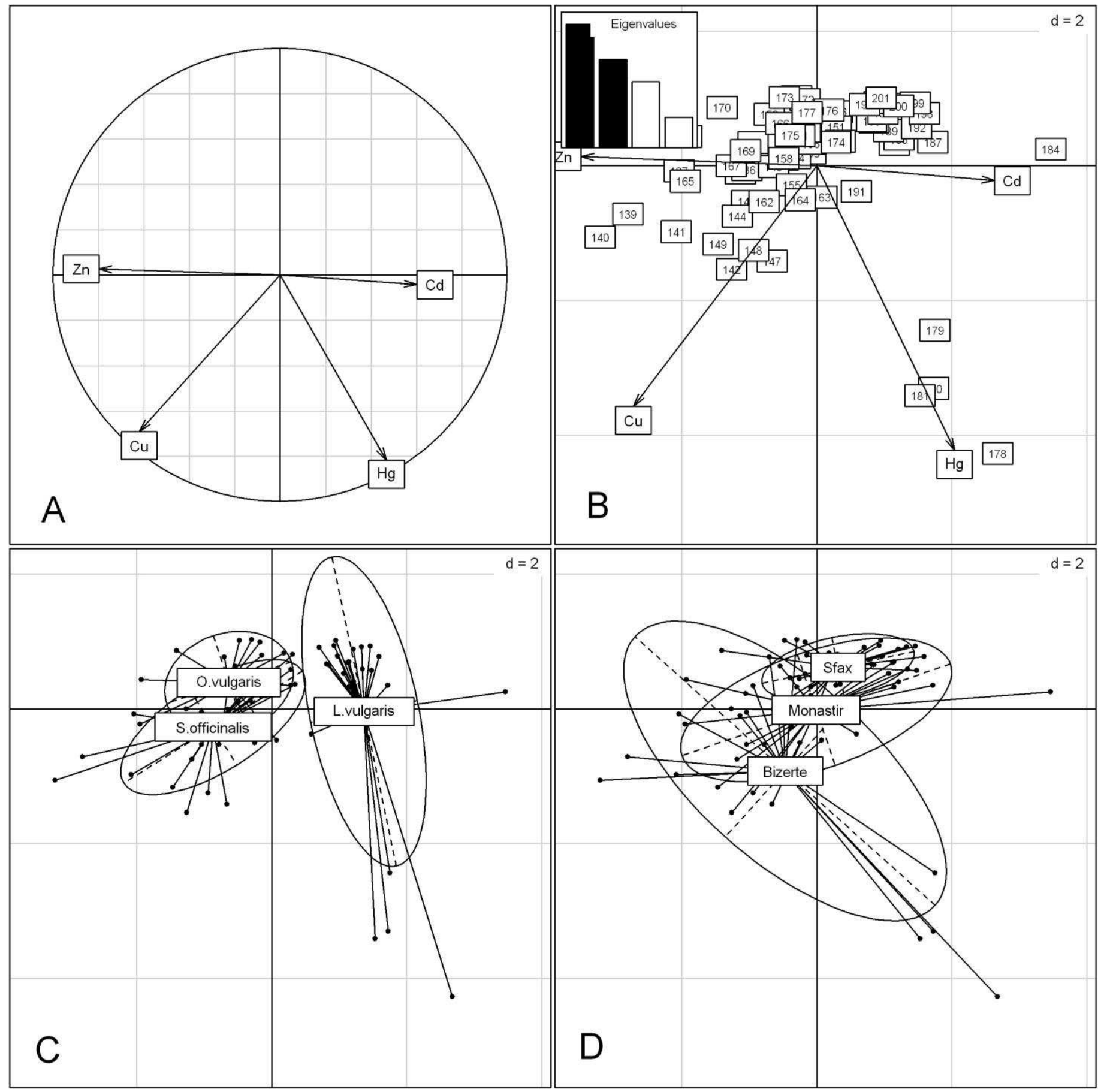

Figure 4: Principal component analysis (PCA) of cephalopods based on metal levels in the arms. A) Correlation bi-plot showing the distribution of the variables. B) Projection of individuals on the correlation bi-plot with eigenvalue of the first two components. C) Grouping individuals by species. D) Grouping individuals by sampling sites. 


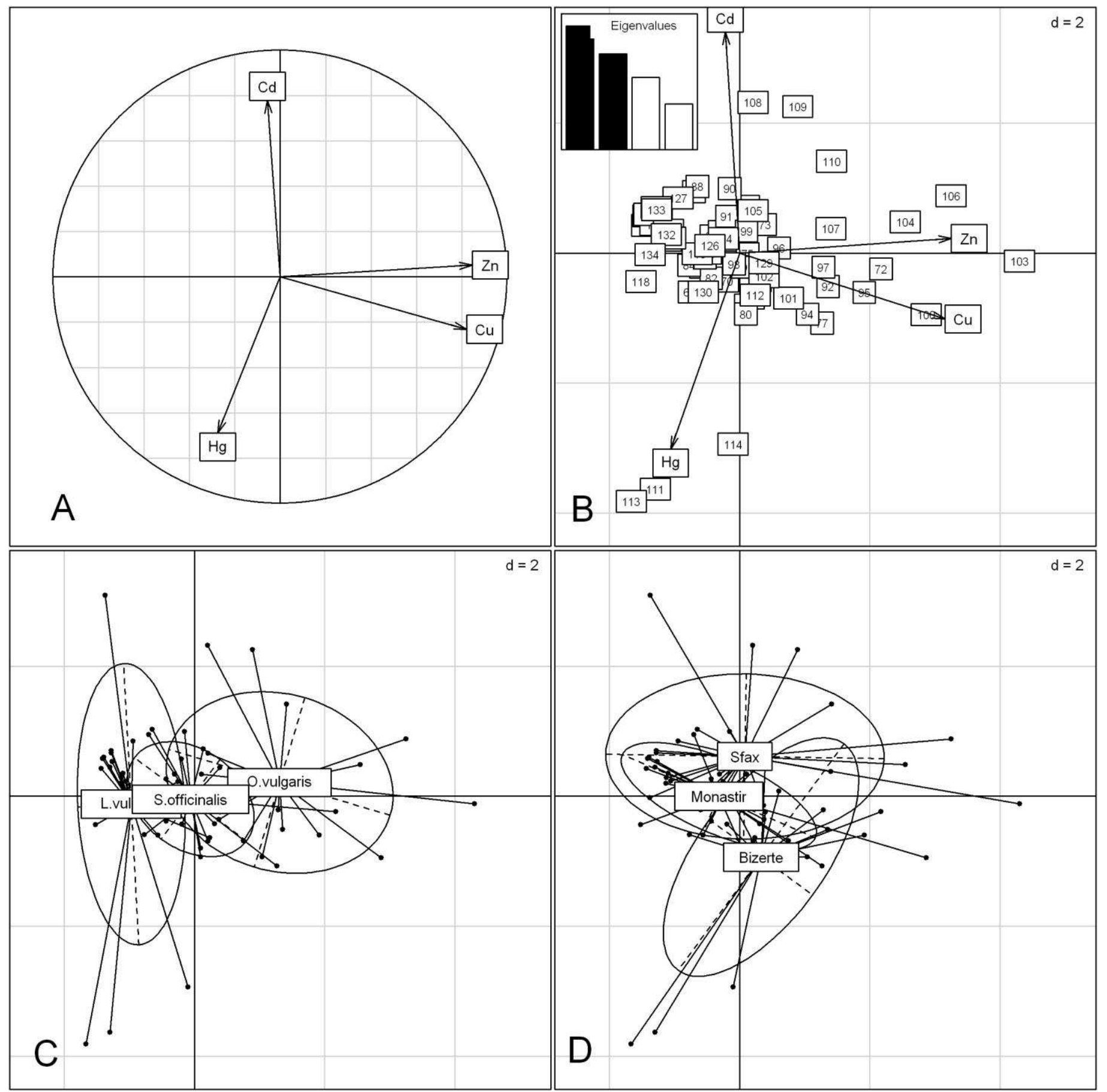

Figure 5: Principal component analysis (PCA) of cephalopods based on metal levels in the mantle. A) Correlation bi-plot showing the distribution of the variables. B) Projection of individuals on the correlation bi-plot with eigenvalue of the first two components. C) Grouping individuals by species. D) Grouping individuals by sampling sites. 
A

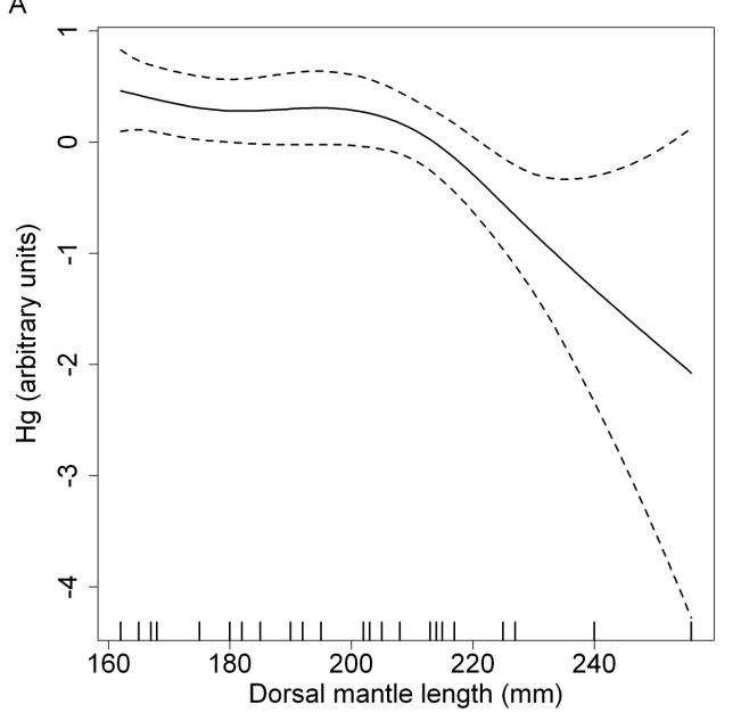

C

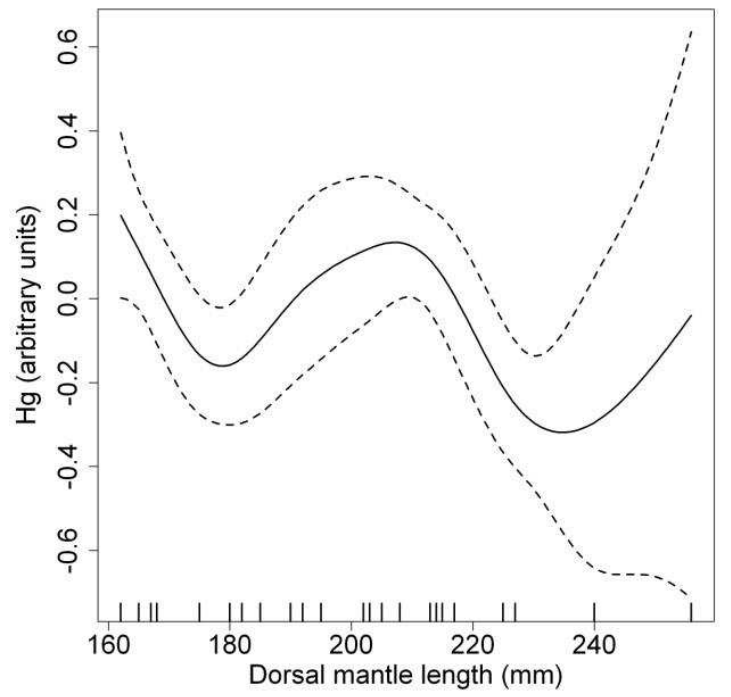

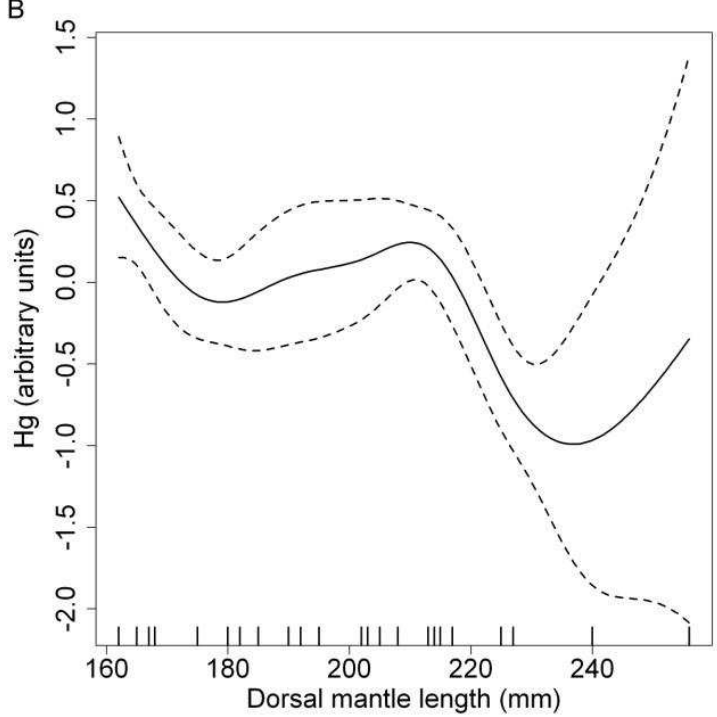

D

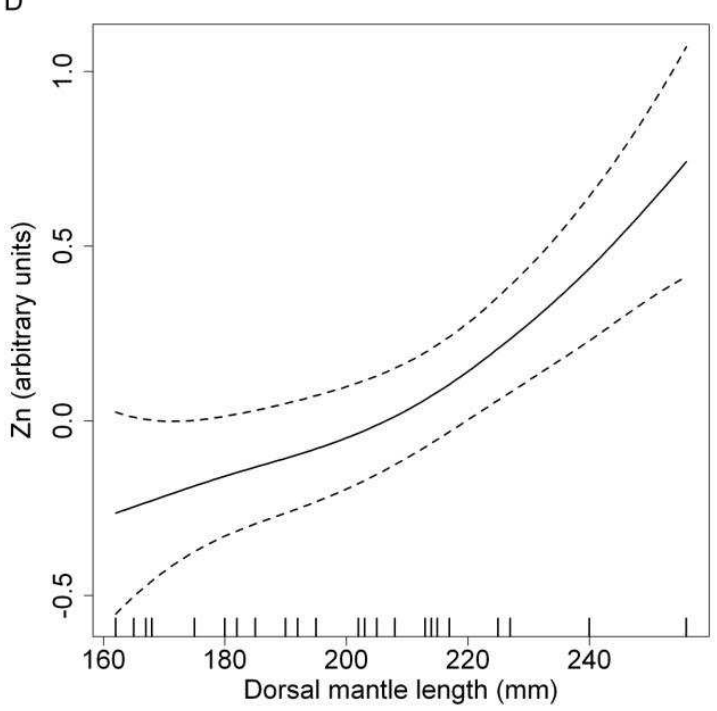

Figure 6: Smoothers for effects of dorsal mantle length on mercury $(\mathrm{Hg})$ concentrations ( $\mu \mathrm{g} \cdot \mathrm{g}^{-1} \mathrm{dw}$ ) in (A) the digestive gland, (B) the mantle and (C) the arms, and on zinc (Zn) concentrations $\left(\mu \mathrm{g} \cdot \mathrm{g}^{-1} \mathrm{dw}\right)$ in $(\mathrm{D})$ the mantle of Loligo vulgaris. The $\mathrm{y}$-axis shows the contribution of the smoother to the predictor function (in arbitrary units). Smoothers illustrate the partial effect of DML, i.e. the effect of DML and once the effects of all other explanatory variables in the model have been taken into account. Dashed lines represent $95 \%$ confidence bands for the smoothers. 


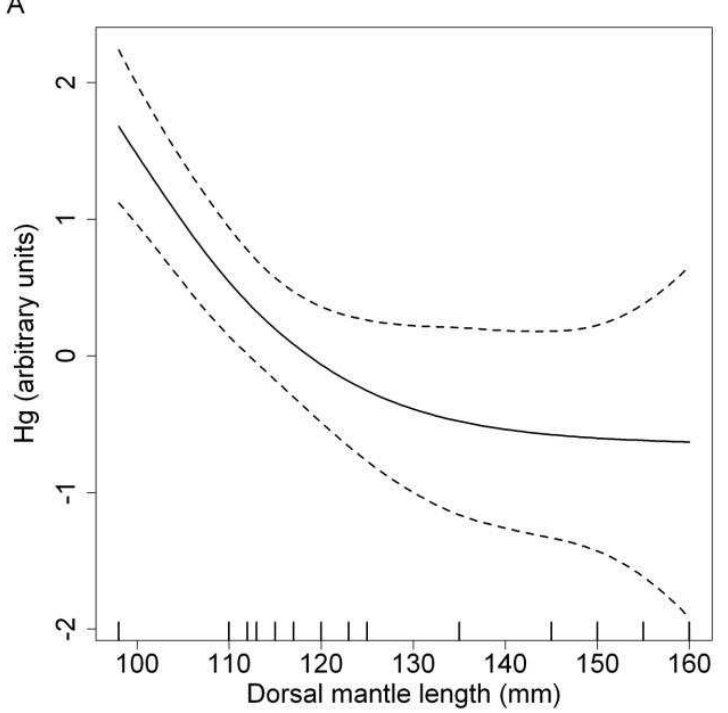

C

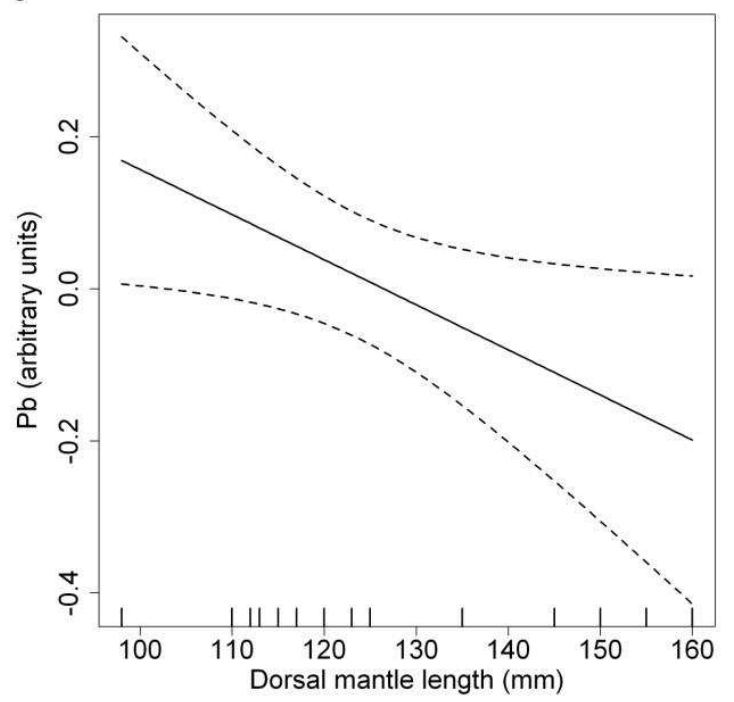

B

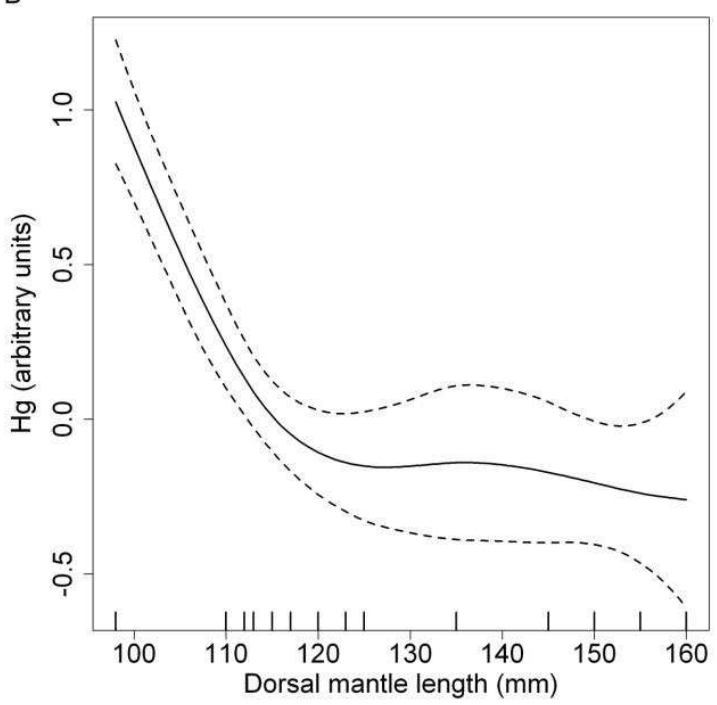

D

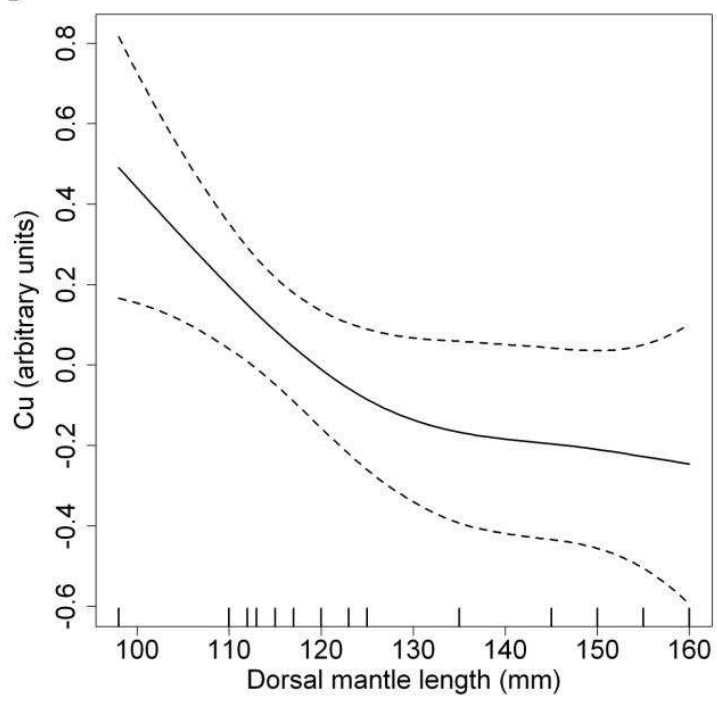

Figure 7: Smoothers for effects on mercury $(\mathrm{Hg})$ concentrations $\left(\mu \mathrm{g} \cdot \mathrm{g}^{-1} \mathrm{dw}\right)$ in $(\mathrm{A})$ the digestive gland and in (B) the mantle, on lead $(\mathrm{Pb})$ concentrations $\left(\mu \mathrm{g} \cdot \mathrm{g}^{-1} \mathrm{dw}\right)$ in $(\mathrm{C})$ the digestive gland and, on copper $(\mathrm{Cu})$ concentrations $\left(\mu \mathrm{g} \cdot \mathrm{g}^{-1} \mathrm{dw}\right)$ in $(\mathrm{D})$ the arms of Octopus vulgaris. The $\mathrm{y}$-axis shows the contribution of the smoother to the predictor function (in arbitrary units). Smoothers illustrate the partial effect of DML, i.e. the effect of DML once the effects of all other explanatory variables in the model have been taken into account. Dashed lines represent $95 \%$ confidence bands for the smoothers. 


\section{Sepia officinalis}

A

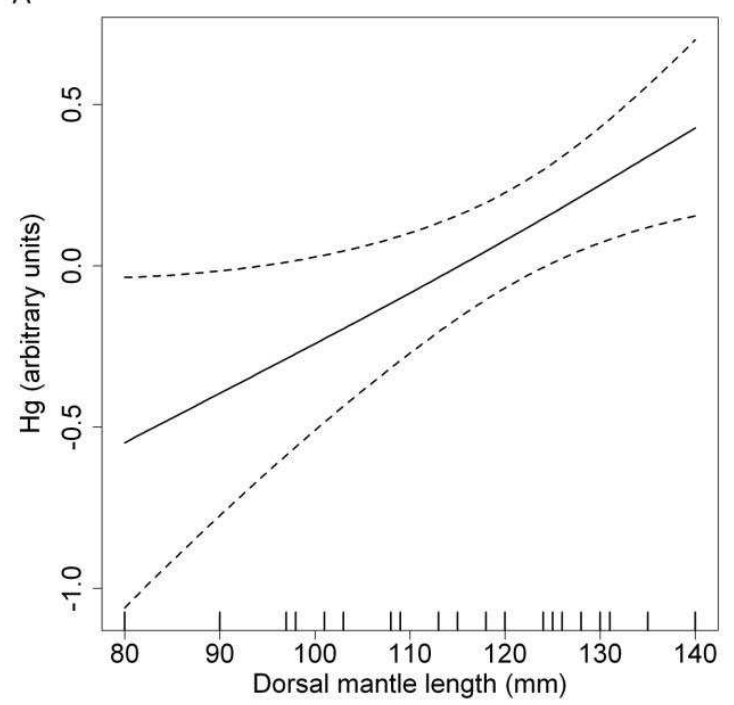

C

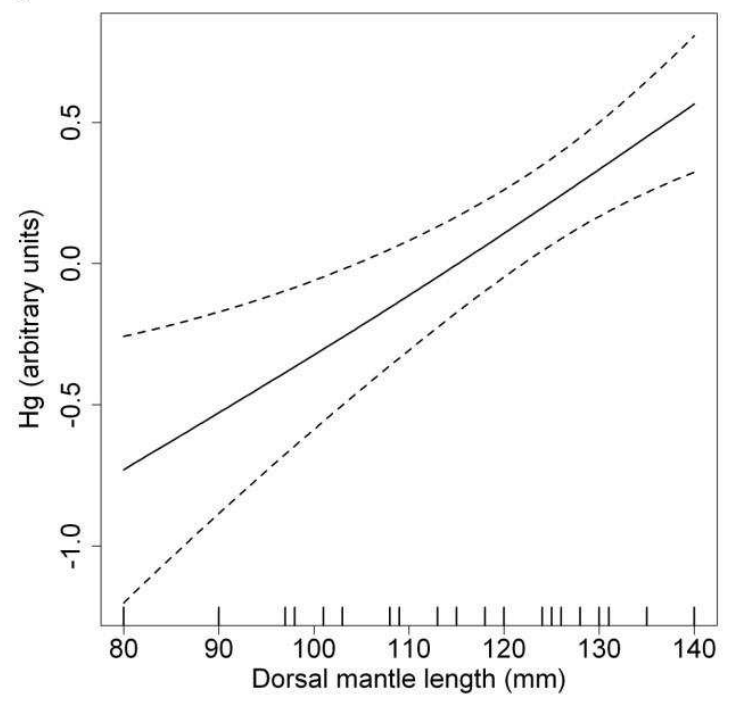

B

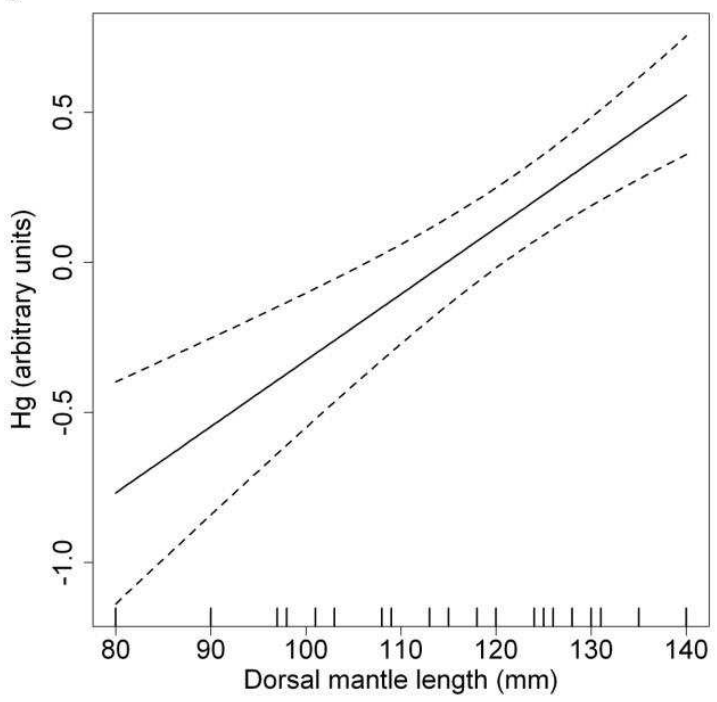

D

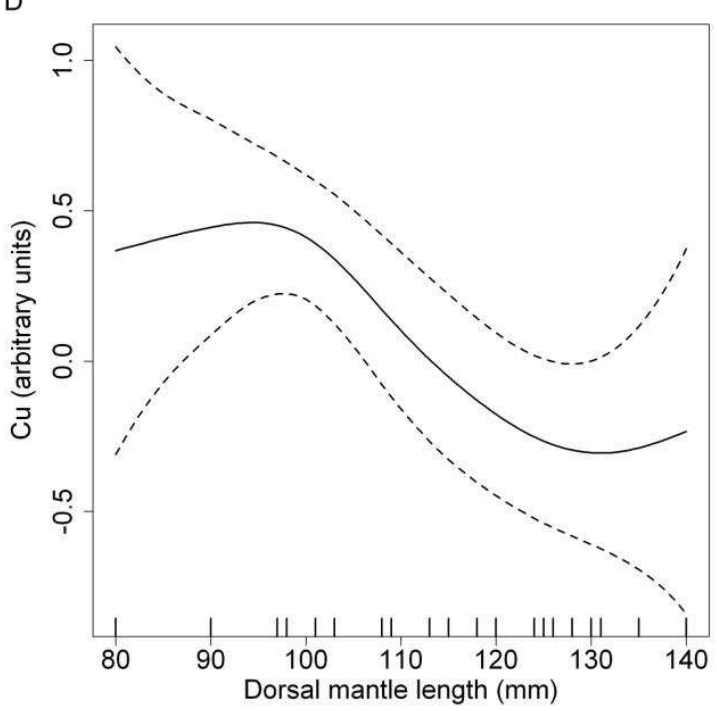

Figure 8: Smoothers for effects on mercury $(\mathrm{Hg})$ concentrations $\left(\mu \mathrm{g} \cdot \mathrm{g}^{-1} \mathrm{dw}\right)$ in (A) the digestive gland, (B) the mantle, and (C) the arms, and on copper $(\mathrm{Cu})$ concentrations $\left(\mu \mathrm{g} \cdot \mathrm{g}^{-1}\right.$ $\mathrm{dw}$ ) in (D) the mantle of Sepia officinalis. The y-axis shows the contribution of the smoother to the predictor function (in arbitrary units). Smoothers illustrate the partial effect of DML, i.e. the effect of DML once the effects of all other explanatory variables in the model have been taken into account. Dashed lines represent 95\% confidence bands for the smoothers. 